\title{
Effectivity Biopsychosocial intervention with Cognitive Behavioral Therapy and Exercise Therapy Program in Chronic Low Back Pain: Meta-analysis
}

\author{
Arif Fadli'), Hanung Prasetya(2), Agus Kristyanto1) \\ 1)Masters Program in Public Health, Universitas Sebelas Maret \\ ${ }^{2)}$ Acupuncture Department, Surakarta Health Polytechnic
}

\section{ABSTRACT}

Background: Pain is a common complaint that causes decreased work productivity and a cause of disability. Biomedical interventions failed to inhibit the increase in chronic low back pain (CLBP) treatment costs. The pain perception of CLBP patients is influenced by emotional psychological and cognitive factors that require biopsychosocial intervention. This study aimed to summarize the existing literature data regarding the effectiveness of biopsychosocial interventions with Cognitive Behavioral Therapy (CBT) and Exercise Therapy Program (ETP) in CLBP.

Subjects and Method: This study was a systematic review and meta-analysis of the Randomized Control Trial study on the electronic database Pubmed, Google scholar, Willey Online Library, Research Gate, Science Direct. Data analysis was performed using the Revman 5.3 program with Cohen's effect size d. Results: There were 7 articles included in this research. The results of the analysis of studies on the effectiveness of biopsychosocial interventions for CBT and ETP in reducing the intensity of CLBP pain were very large with the effect size $(\mathrm{d}=-1.31 ; 95 \% \mathrm{CI}=-2.39$ to $-0.23 ; \mathrm{p}$ $<0.001)$, while the effect size of the disability index was very large $(\mathrm{d}=-1.62 ; 95 \% \mathrm{CI}=-2.70$ to -0.54 ; $\mathrm{p}<0.001$ ).

Conclusion: Biopsychosocial interventions for CBT and ETP are effective in reducing the pain and disability index of CLBP. The effectiveness of biopsychosocial interventions with CBT and ETP methods is due to the patient's efficacy in completing the rehabilitation program.

Keywords: biopysichosocial, CBT, ETP, CLBP

\section{Correspondence:}

Arif Fadli. Masters Program in Public Health Sciences, Universitas Sebelas Maret, Jl. Ir. Sutami 36A, Surakarta 57126, Central Java. Email: Ariffadli950@gmail.com. Mobile: +6281355377050.

Cite this as:

Fadli A, Prasetya H, Kristyanto A (2021). Effectivity Biopsychosocial intervention with CBT and ETP in CLBP: Meta-analysis. Indones J Med. 06(02): 177-193. https://doi.org/10.26911/theijmed.2021.06.02.07.

(c) (i) (2) Indonesian Journal of Medicine is licensed under a Creative Commons (c) ${ }_{\mathrm{EY} \text { NG SA }}$ Attribution-NonCommercial-ShareAlike 4.o International License.

\section{BACKGROUND}

Pain is a common complaint that causes a decrease in work productivity and disability which requires large costs for health care (Lane et al., 2018). Chronic pain is influenced by cognitive and psychological factors in $37 \%$ of the population of developed countries and $41 \%$ of developing countries (Velly and Mohit, 2018). 46\% of the human population had complained of low back pain (Lane et al., 2018). The non-specific prevalence of chronic low back pain (CLBP) was $40 \%$ of chronic pain (Manchikanti et al., 2014).

Non-specific complaints of CLBP are due to anatomic susceptibility and nonanatomical multi-dimensional causes that fail in biomedical interventions (Synnott et al., 2016). 90\% of the diagnostic enforcement of LBP pathoanatomy is unclear with biomedical interventions failing to inhibit the increase in medical costs, degree of 
disability and chronic pain (O'Sullivan et al, 2018). CLBP has a major impact on the socioeconomic conditions of the family (Ung et al., 2014). The patient burden increases due to opioid addiction, financial difficulties and depression (Dinakar and Stillman, 2016).

Pain perception is influenced by psychological and cognitive factors with the identification of neuroimaging technology, the level of changes in the central nervous system (Malfliet et al, 2018). Pain as a response to a nociceptive stimulus develops into chronic pain due to central sensinitation (Pak et al., 2018). Brain functional dysregulation is due to central sensinitation in the form of nociceptive hyperexcitability which causes hyperalgesia, allodynia, and pain hyperexcitation (Neblett et al., 2017). The failure of the chronic pain adaptation mechanism is due to pain modulation dysfunction in the descending tractuscorticospinalis (Serrano et al, 2020). Central level pain modulation is influenced by genetic factors, physical traumatic injury, emotional distress, and history of opioid abuse (Neblett et al., 2017).

The promotive and preventive efforts of CLBP at the clinical expression stage aim to intervene in biopsychosocial determinants in order to achieve disability limitations and rehabilitation of bodily functions (Murti, 2018). Biopsychosocial intervention was done with verbal persuasion education on problem solving for people who want to change their self-efficacy to improve problem-solving abilities (Rustika, 2016). The educational process is centered on the patient through gradual problem solving techniques over a long period of time (Schiavo, 2007). The self-efficacy of CLBP patients reflects the patient's belief in the patient's ability to control the barrier to emotional perception of pain and disability (Prestwich et al., 2018).
Associative learning of protective motion behavior and pain perception affects joint motion receptors to be adapted to painless motion in the brain (Alaiti et al, 2020). The patient's functional improvement is achieved through the pain inhibition mechanism in the corticospinal tract in painless motor control (Martin et al, 2019). Neuroplastic changes facilitate neurogenesis effects of exercise therapy programs and pain perception education (Martin et al, 2019). Changes in the cognitive behavior of CLBP patients can reduce pain and improve the patient's quality of life (Chao and Ford, 2019).

The results of previous studies that core musclestability exercise and CBT were more effective in increasing the self-efficacy and muscle strength of CLBP patients compared to core musclestability exercise alone (Bagheri et al., 2020). Whereas a systematic review and meta-analysis of 18 articles on CBT and exercise therapy for chronic musculo-skeletal pain patients with a small effect of reducing pain and a moderate effect on the disability index (Cheng and Cheng, 2019). Looking at the description above, this systematic review aimed to summarize the data in the existing literature regarding the effectiveness of biopsychosocial interventions with Cognitive Behavioral Therapy (CBT) and Exercise Therapy Program (ETP) on Chronic Low Back Pain (CLBP).

\section{SUBJECTS AND METHOD \\ 1. Study Design}

This was a systematic review and metaanalysis using PICOS frame work, namely chronic low back pain (population/ problem), cognitive behavioral therapy and exercise therapy program (intervention), exercise therapy program (comparison), pain scale and disability index (outcome). The data research study was in the article 
Randomized Control Trial (study design). Search for relevant articles was carried out on published articles from 2011 to 2020 in 5 electronic databases: PubMed, Googlescholar, Willey Online Library, Research Gate, ScienceDirect.

The combination of keywords used for article selection: ((pain OR "lumbar pain" OR "chronic pain" OR "chronic low back pain") AND ("cognitive behavioral therapy") AND (exercise OR "therapeutic exercise" OR "physical exercise "OR" exercise therapy program ")).

\section{Inclusion Criteria}

The inclusion criteria in this study were (1) free full text articles of randomized control trial study design, (2) age of study subjects $>18$ years of age who underwent pain rehabilitation in health care facilities, (3) study subjects complained of non-specific CLBP >3 months, (4) the intervention group with CBT and ETP, while the control group received ETP, (5) the percentage of data on subjects dropping out of treatment in the study was $\geq 25 \%$ with the results of measuring pain intensity and disability index.

\section{Exclusion Ctriteria}

The exclusion criteria in this study were (1) specific pain complaints due to neurological injury and the presence of cancer, (2) the presence of cognitive disorders and comorbid mental disorders other than depression and anxiety, (3) articles other than using English were not included in this systematic review.

\section{Operational Definition of Variable}

Chronic low back pain was a non-specific chronic low back pain complaint complained by patients $\geq 3$ months. Cognitive behavioral therapy was a cognitive behavioral intervention with distraction and counseling on patterns of daily activities to control CLBP pain. Exercise therapy program was an exercise therapy program to establish cognitive behavioral memory of normal motor control without pain.

\section{Data Analysis}

Data analysis was performed using the Revman 5.3 program with Cohen's d effect size, if the $\mathrm{p} \geq 0.050$ or the $\mathrm{I}^{2}$ value $<50 \%$ then a fixed effect was used, if the $\mathrm{p}<0.050$ or the value $\mathrm{I}^{2}>50 \%$ then a random effect was used.

\section{RESULTS}

The process of searching for articles by searching through a database with journals can be seen in Figure 1. The final result of the article review process showed that there were 7 articles that fulfill the quantitative requirements for a meta-analysis which were from Italy (3 articles), China (1 article), Australia (1 article), Pakistan (1 article), and Nigeria (1).

Table 2 data is the result of quality assessment of 7 articles on the aspect of risk of bias publication with the Physiotherapy Evidence Database (PEDro) Scale instrument with a total score classification of $0-3$ bad rating categories, 4-5 moderate assessment categories, 6-8 good assessment categories, and the 9-10 assessment categories are very good, while the evaluation of the exercise program intervention, a total Pedro score of $8 / 10$ is optimum. The results were shown in Table 2. Table 3. showed a meta-analysis of the effectiveness of biopsychosocial interventions for CBT and ETP on pain intensity in 579 CLBP patients.

Figure 1. showed a forest plot of the effectiveness of biopsychosocial interventions for CBT and ETP on the pain intensity of 579 CLBP patients. Forest plot showed the effectiveness of biopsychosocial intervention therapy for CBT and ETP (intervention group) in reducing the pain intensity of CLBP patients compared to ETP alone (control group) was very large with an effect size $(d=-1.31 ; 95 \% C I=-2.39$ 
to -0.23), and it was statistically significant $(\mathrm{p}<0.001)$. Heterogeneity $\left(\mathrm{I}^{2}\right)=97 \%$ indicated heterogeneous data distribution (random effect model).

Figure 2 showed the forest plot of the efficacy of biopsychosocial interventions for CBT and ETP at the pain intensity of 532 CLBP patients. Forest plot showed the efficacy of biopsychosocial intervention therapy for CBT and ETP (intervention group) in reducing the pain intensity of CLBP patients compared to ETP alone (control group) is very large with an effect size $(\mathrm{d}=-1.31 ; 95 \% \mathrm{CI}=-2.41$ to -0.22$)$, and it was statistically significant ( $p<0.001)$, Heterogeneity $\quad\left(\mathrm{I}^{2}\right)=96 \% \quad$ indicates heterogeneous data distribution (random effect model).

Figure 3 showed that there was publication bias with an asymmetric axis indication, which was shown by the distribution of 3 funnel plots on the left and 4 funnel plots on the right. Standard error funnel plot on the left was $0.42-0.20$ and standard error on the right funnel plot was 0.45 - 0.15. Meanwhile, Figure 4. showed that there was publication bias with an asymmetric axis indication, which was shown by the distribution of 3 funnel plots on the left and 4 funnel plots on the right. Standard error funnel plot on the left was $0.42-0.21$ and standard error on the right funnel plot was $0.45-0.15$.

Table 3 showed a meta-analysis of the effectiveness of biopsychosocial interventions for CBT and ETP on the disability index of 579 CLBP patients. Graph 5 shows the forest plot of the effectiveness of biopsychosocial interventions for CBT and ETP on the disability index of 579 CLBP patients. Forest plot shows the effectiveness of biopsychosocial intervention therapy for CBT and ETP (intervention group) on the disability index of CLBP patients compared to ETP alone (control group) is very large with an effect size $(\mathrm{d}=-1.62)$ CI $(-2.70$ to 0.54). Statistical analysis showed very significant results (p <0.001). Heterogeneity $\left(\mathrm{I}^{2}\right)=96 \%$ indicated a heterogeneous data distribution (random effect model).

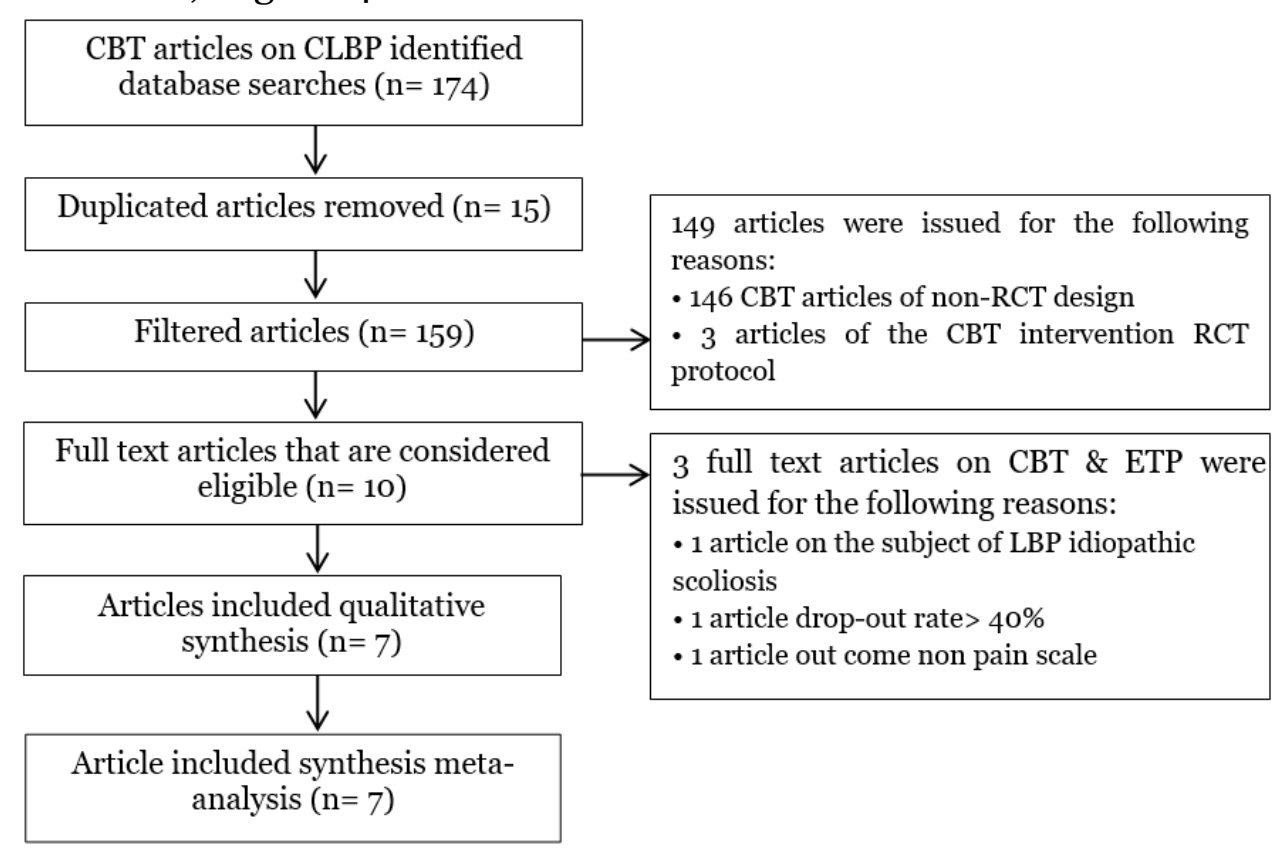

Figure 1. The article search flow chart diagram with PRISMA-P 
Table 1. Characteristics of articles included in the qualitative analysis and meta-analysis

\begin{tabular}{|c|c|c|c|c|}
\hline $\begin{array}{c}\text { Author } \\
\text { and Year }\end{array}$ & Problem & $\begin{array}{c}\text { Characteristics } \\
\text { of Subjects }\end{array}$ & Intervention (I) \& Comparison (C) & Outcome \\
\hline $\begin{array}{l}\text { Monticone } \\
\text { et al., } \\
2013 \text {, } \\
\text { Italia }\end{array}$ & CLBP & $\begin{array}{l}\text { - subject: } 90(90), \\
\text { I: } 45(45), \\
\text { K: } 45(45) \\
\text { - mean age: } 49.3\end{array}$ & $\begin{array}{l}\text { I: CBT + prog. TL individual, K: prog. Individual TL, } \\
\text { dosage: prog. Individual TL } 2 \text { x / week for } 5 \text { weeks, } \\
\text { CBT 1x / week for } 5 \text { weeks, follow-up observation for } \\
1 \text { year }\end{array}$ & $\begin{array}{l}\text { I: NRS significant, K: NRS non-significant } \\
\text { I: RMDQ is significant, K: RMDQ is non- } \\
\text { significant }\end{array}$ \\
\hline $\begin{array}{l}\text { Angela et } \\
\text { al., 2013, } \\
\text { China }\end{array}$ & CLBP & $\begin{array}{l}\text { - subject: } 47(47) \\
\text { I: } 24(24) \\
\text { K: } 23(23) \\
\text { - mean age: } 37.3\end{array}$ & $\begin{array}{l}\text { I: CBT + prog. Individual stratified TL, K: prog. } \\
\text { Individual gradual TL, dose: } 11 \text { therapy sessions, } \\
\text { follow-up observation for } 3 \text { months }\end{array}$ & $\begin{array}{l}\text { I\&K: significant NRS } \\
\text { I\&K: RMDQ is significant }\end{array}$ \\
\hline $\begin{array}{l}\text { Macedo et } \\
\text { al., 2012, } \\
\text { Australia }\end{array}$ & CLBP & $\begin{array}{l}\text { - subjects: } 175(155) \text {, } \\
\text { I: } 86(80), \\
\text { K: } 86(75) \\
\text { - mean age: } 49.2\end{array}$ & $\begin{array}{l}\text { I: stratified individual CBT + TL, K: stratified } \\
\text { individual TL, dose: } 14 \text { therapy sessions for } 8 \text { weeks, } \\
\text { follow-up observation for } 1 \text { year }\end{array}$ & $\begin{array}{l}\text { I\&K: significant NRS } \\
\text { I\&K: RMDQ is non-significant }\end{array}$ \\
\hline $\begin{array}{l}\text { Monticone } \\
\text { et al., } \\
\text { 2014, } \\
\text { Italia }\end{array}$ & CLBP & $\begin{array}{l}\text { - subject: } 20(20), \\
\text { I: } 10(10), \\
\text { K: } 10(10) \\
\text { - mean age: } 57.75\end{array}$ & $\begin{array}{l}\text { I: individual CBT + TL, K: individual TL, dose: } \\
\text { individual TL 2x / week \& CBT 1x / week for } 8 \text { weeks, } \\
3 \text { months follow-up observation }\end{array}$ & $\begin{array}{l}\text { I: NRS significant, K: NRS non-significant } \\
\text { I: ODI is significant, K: ODI is non- } \\
\text { significant }\end{array}$ \\
\hline $\begin{array}{l}\text { Khan et } \\
\text { al., 2014, } \\
\text { Pakistan }\end{array}$ & CLBP & $\begin{array}{l}\text { - subject: } 54(54), \\
\text { I: } 27(27), \\
\text { K: } 27(27) \\
\text { - mean age: } 39.6\end{array}$ & $\begin{array}{l}\text { I: CBT + TL is not focused individually, K: + TL is } \\
\text { not focused individually, dose: } 3 \mathrm{x} / \text { week for } 12 \\
\text { weeks, follow-up observation for } 1 \text { year }\end{array}$ & $\begin{array}{l}\text { I: VAS significant, K: VAS non-significant } \\
\text { I: RMDQ is significant, K: RMDQ is non- } \\
\text { significant }\end{array}$ \\
\hline $\begin{array}{l}\text { Monticone } \\
\text { et al., } \\
\text { 2016, } \\
\text { Italia }\end{array}$ & CLBP & $\begin{array}{l}\text { - subjects: } 150(129) \\
\text { I: } 75(65), \\
\text { K: } 75(64) \\
\text { - mean age: } 53.5\end{array}$ & $\begin{array}{l}\text { I: CBT + individual TL program, K: individual TL } \\
\text { program, dose: individual TL program 2x / week for } \\
5 \text { weeks, CBT 1x / week for } 5 \text { weeks, follow-up } \\
\text { observation for } 2 \text { years }\end{array}$ & $\begin{array}{l}\text { I: NRS significant, K: NRS non-significant } \\
\text { I: ODI is significant, K: ODI is non- } \\
\text { significant }\end{array}$ \\
\hline $\begin{array}{l}\text { Aliyu et } \\
\text { al., 2018, } \\
\text { Nigeria }\end{array}$ & CLBP & $\begin{array}{l}\text { - subjects: } 46(37) \\
\text { I: } 23(19), \\
\text { K: } 23(18) \\
\text { - mean age: } 42.27\end{array}$ & $\begin{array}{l}\text { I: CBT + LSE, K: LSE, dose: LSE 3x / week for } 6 \\
\text { weeks, CBT 2x / week for } 6 \text { weeks, follow-up } \\
\text { observation therapy was not ordered. }\end{array}$ & $\begin{array}{l}\text { I: VAS is significant, } \mathrm{K} \text { : VAS is significant } \\
\mathrm{I} \text { : ODI is significant, K: ODI is significant }\end{array}$ \\
\hline
\end{tabular}


Fadli et al./ Effectivity Biopsychosocial intervention with CBT and ETP in CLBP

Table 2. The PEDro scale for assessing the quality of the studies included in the meta-analysis

\begin{tabular}{|c|c|c|c|c|c|c|c|c|c|c|c|c|}
\hline \multirow{2}{*}{ Study } & \multicolumn{11}{|c|}{ PEDro score assessment items } & \multirow{2}{*}{ Total score } \\
\hline & $\mathbf{1}$ & 2 & 3 & 4 & 5 & 6 & 7 & 8 & 9 & 10 & $\mathbf{1 1}$ & \\
\hline Monticone et al., 2013 & + & + & + & + & + & - & + & + & + & - & - & $8 / 10$ \\
\hline Angela et al., 2013 & + & + & + & - & + & - & + & + & + & - & - & $7 / 10$ \\
\hline Macedo et al., 2012 & + & + & + & + & + & - & + & + & + & - & - & $8 / 10$ \\
\hline Monticone et al., 2014 & + & + & + & - & + & - & + & + & + & - & - & $7 / 10$ \\
\hline Khan et al., 2014 & + & + & + & - & + & - & + & + & + & - & - & $7 / 10$ \\
\hline Monticone et al., 2016 & + & + & + & - & + & - & + & + & + & - & - & $7 / 10$ \\
\hline Aliyu et al., 2018 & + & + & + & + & + & + & - & - & - & + & - & $7 / 10$ \\
\hline $\begin{array}{l}\text { Item kriteria PEDro sco } \\
\text { (1) eligibility criteria, } \\
\text { (2) random allocation } \\
\text { (3) concealed allocati } \\
\text { (4) baseline comparib } \\
\text { (5) blind subjects, } \\
\text { (6) blind therapists, } \\
\text { (7) blind assessors, } \\
\text { (8) adequate follow-u } \\
\text { (9) intention to threat } \\
\text { (10) between group cc } \\
\text { (11) point estimate d }\end{array}$ & & & & & & & & & & & & \\
\hline Description of sign $(+)$ : & ): & 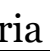 & $d$ & & & & & & & & & \\
\hline
\end{tabular}


Fadli et al./ Effectivity Biopsychosocial intervention with CBT and ETP in CLBP

Table 3. Effectiveness of biopsychosocial interventions for CBT and ETP on pain intensity

\begin{tabular}{lllcc}
\hline \multicolumn{1}{c}{ Author (year) } & Country & SMD & 95 \% CI & p \\
\hline Monticone et al., 2013 & Italy & -4.81 & $(-5.64$ to -3.98$)$ & $<0.001$ \\
Lee et al., 2013 & China & -0.33 & $(-0.90$ to 0.25) & 0.267 \\
Macedo et al., 2012 & Australia & 0.00 & $(-0.30$ to 0.30$)$ & $<0.05$ \\
Monticone et al., 2014 & Italy & 0.00 & $(-0.88$ to 0.88$)$ & $<0.001$ \\
Khan et al., 2014 & Pakistan & -1.97 & $(-2.63$ to -1.31$)$ & $<0.001$ \\
Monticone et al., 2016 & Italy & -2.02 & $(-2.41$ to -1.62$)$ & $<0.001$ \\
Aliyu et al., 2018 & Nigeria & -0.16 & $(-0.74$ to 0.42$)$ & $<0.001$ \\
\hline
\end{tabular}

\begin{tabular}{|c|c|c|c|c|c|c|c|c|c|}
\hline \multirow[b]{2}{*}{ Study or Subgroup } & \multicolumn{3}{|c|}{ CBT \& ETP } & \multicolumn{3}{|c|}{ ETP } & \multicolumn{2}{|r|}{ Std. Mean Difference } & \multirow{2}{*}{$\begin{array}{l}\text { Std. Mean Difference } \\
\text { N, Random, } 95 \% \mathrm{Cl}\end{array}$} \\
\hline & Mean & SD & Total & Mean & SD & Total & Weight & IV, Random, $95 \% \mathrm{Cl}$ & \\
\hline Aliyu et al 2018 & 3.11 & 1.24 & 23 & 3.33 & 1.41 & 23 & $14.4 \%$ & $-0.16[-0.74,0.42]$ & \\
\hline Khan et al, 2014 & 2.66 & 1.39 & 27 & 5.25 & 1.19 & 27 & $14.2 \%$ & $-1.97[-2.63,-1.31]$ & $\rightarrow$ \\
\hline Lee et al, 2013 & 2.42 & 1.95 & 24 & 3.14 & 2.37 & 23 & $14.4 \%$ & $-0.33[-0.90,0.25]$ & 1 \\
\hline Macedo et al, 2012 & 3.7 & 2.7 & 86 & 3.7 & 2.6 & 86 & $14.8 \%$ & $0.00[-0.30,0.30]$ & \\
\hline Monticone et al 2014 & 2 & 1 & 10 & 2 & 2 & 10 & $13.7 \%$ & $0.00[-0.88,0.88]$ & \\
\hline Monticone et al, 2013 & 1.47 & 1.1 & 45 & 6.24 & 0.85 & 45 & $13.8 \%$ & $-4.81[-5.64,-3.98]$ & $\rightarrow$ \\
\hline Monticone et al, 2016 & 1.4 & 1.2 & 75 & 4.5 & 1.8 & 75 & $14.7 \%$ & $-2.02[-2.41,-1.62]$ & - \\
\hline Total (95\% Cl) & & & 290 & & & 289 & $100.0 \%$ & $-1.31[-2.39,-0.23]$ & \\
\hline $\begin{array}{l}\text { Heterogeneity: Tau }{ }^{2}=2 \\
\text { Test for overall effect: } Z\end{array}$ & $\begin{array}{l}01 ; \mathrm{Chi}^{2} \\
=2.39(\mathrm{~F}\end{array}$ & $\begin{array}{l}=175 \\
=0.02\end{array}$ & 29, df $=$ & $=6(P<$ & 0.000 & $01)_{1}^{2}=$ & $97 \%$ & & \begin{tabular}{lllll}
-4 & -2 & 0 & 2 & 4 \\
\multicolumn{3}{c}{ CBT \& ETP ETP }
\end{tabular} \\
\hline
\end{tabular}

Figure 1. Forest plot of the effectiveness of CBT and ETP biopsychosocial interventions on pain intensity

$\begin{array}{llll}\text { CBT \& ETP } & \text { ETP } & \text { Std. Mean Difference } & \text { Std. Mean Difference }\end{array}$

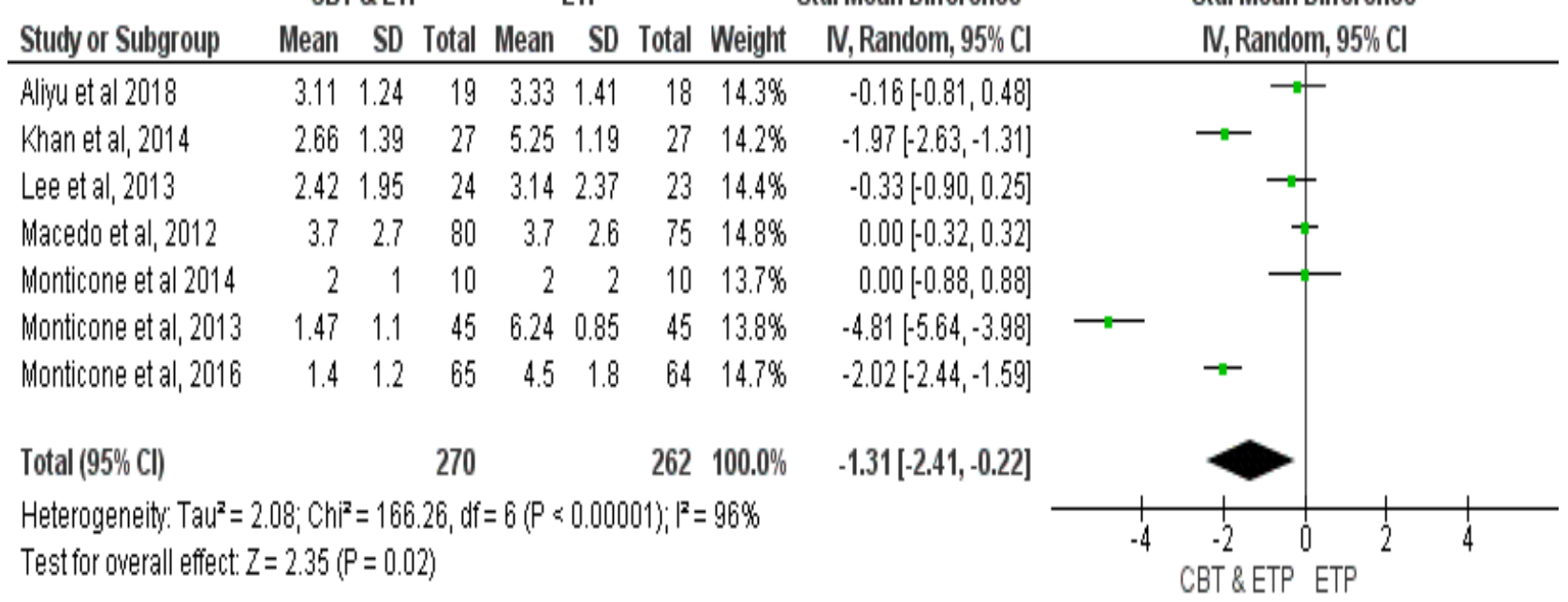

Figure 2. Forest plot of the efficacy of biopsychosocial interventions for CBT and ETP on pain intensity 
Fadli et al./ Effectivity Biopsychosocial intervention with CBT and ETP in CLBP

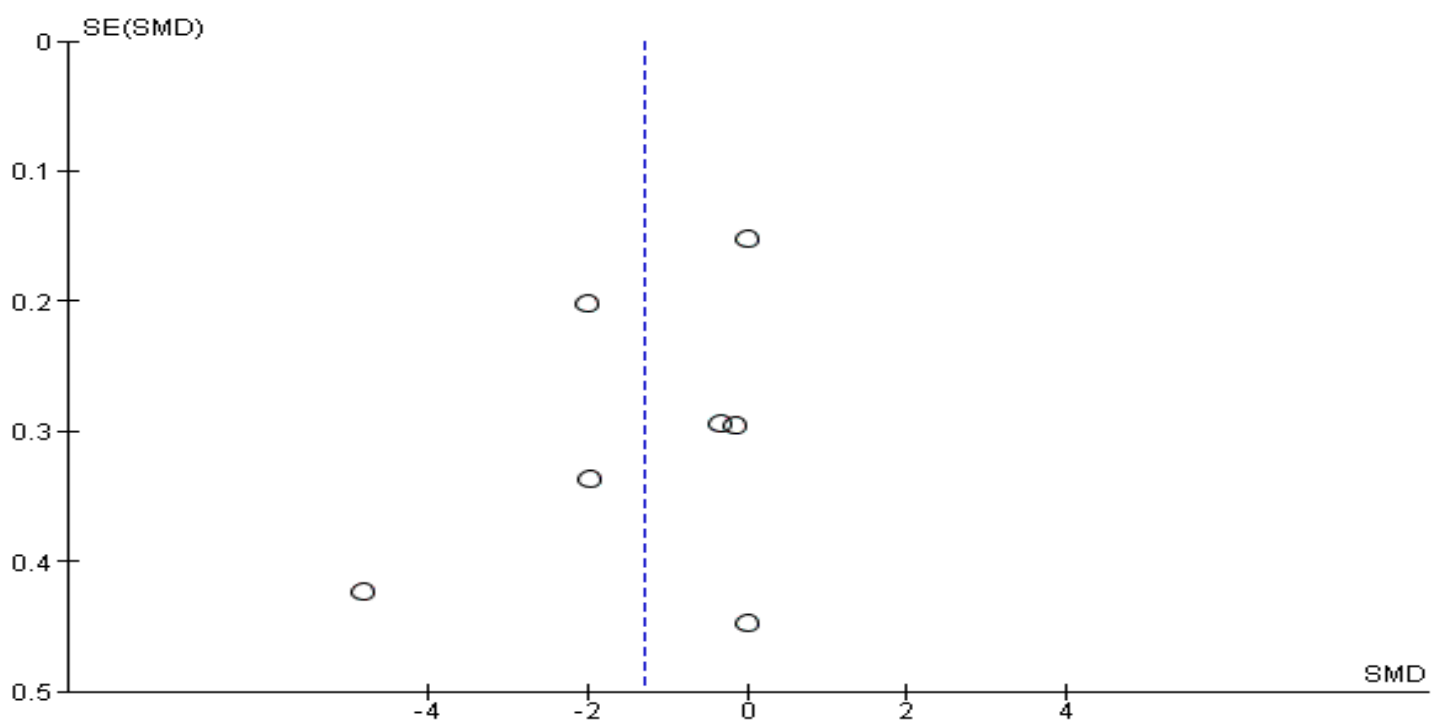

Graph 3. Funnel plot of the effectiveness of biopsychosocial interventions for CBT and ETP on pain intensity

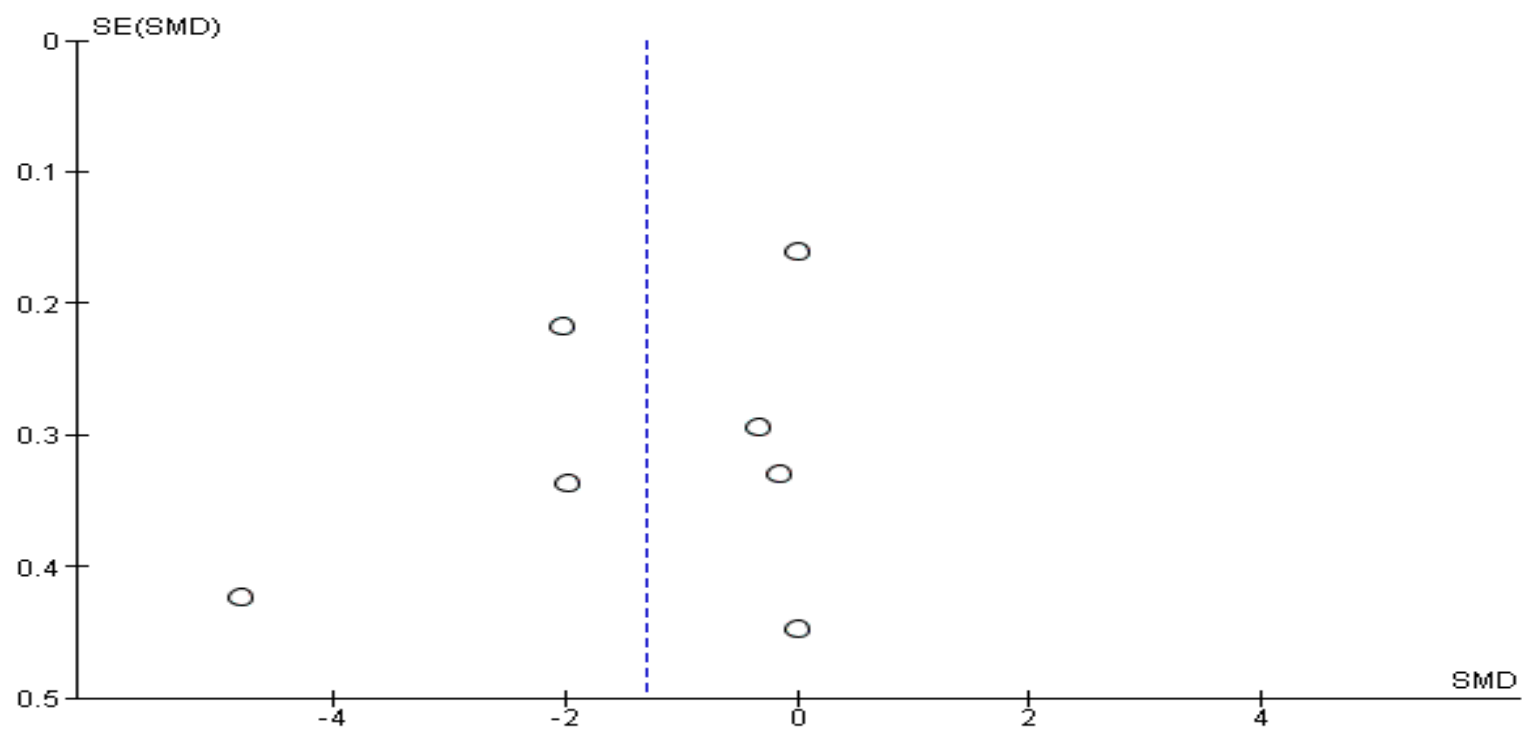

Graph 4. Funnel plot of the efficacy of biopsychosocial interventions for CBT and ETP on pain intensity

Table 3. Effectiveness of biopsychosocial interventions for CBT and ETP on the disability index

\begin{tabular}{lllcc}
\hline \multicolumn{1}{c}{ Author (year) } & \multicolumn{1}{c}{ Country } & SMD & 95 \% CI & p \\
\hline Monticone et al, 2013 & Italy & -5.38 & $(-6.29 \mathrm{~s} / \mathrm{d}-4.48)$ & $<0.001$ \\
Lee et al, 2013 & China & -0.25 & $(-0.83 \mathrm{~s} / \mathrm{d}$ o.32) & 0.613 \\
Macedo et al, 2012 & Australia & -0.09 & $(-0.39 \mathrm{~s} / \mathrm{d} 0.21)$ & $<0.05$ \\
Monticone et al, 2014 & Italy & -1.86 & $(-2.95 \mathrm{~s} / \mathrm{d}-0.77)$ & $<0.001$ \\
Khan et al, 2014 & Pakistan & -1.96 & $(-2.61 \mathrm{~s} / \mathrm{d}-1.30)$ & 0.000 \\
Monticone et al, 2016 & Italy & -1.89 & $(-2.28 \mathrm{~s} / \mathrm{d}-1.50)$ & $<0.001$ \\
Aliyu et al, 2018 & Nigeria & -0.19 & $(-0.77 \mathrm{~s} / \mathrm{d}-0.39)$ & $<0.001$ \\
\hline
\end{tabular}


Fadli et al./ Effectivity Biopsychosocial intervention with CBT and ETP in CLBP

\begin{tabular}{|c|c|c|c|c|c|c|c|c|c|}
\hline \multirow[b]{2}{*}{ Study or Subgroup } & \multicolumn{3}{|c|}{ CBT \& ETP } & \multicolumn{3}{|c|}{ ETP } & \multicolumn{2}{|r|}{ Std. Mean Difference } & \multirow{2}{*}{$\begin{array}{l}\text { Std. Mean Difference } \\
\text { N, Random, } 95 \% \text { Cl }\end{array}$} \\
\hline & Mean & SD & Total & Mean & SD & Total & Weight & IV, Random, $95 \% \mathrm{Cl}$ & \\
\hline Aliyu et al 2018 & 27.16 & 19.14 & 23 & 30.22 & 11.98 & 23 & $14.5 \%$ & $-0.19[-0.77,0.39]$ & $\rightarrow$ \\
\hline Khan et al, 2014 & 5.33 & 2.67 & 27 & 9.88 & 1.84 & 27 & $14.3 \%$ & $-1.96[-2.61,-1.30]$ & $\rightarrow$ \\
\hline Lee et al, 2013 & 18.9 & 14.02 & 24 & 22.55 & 14.33 & 23 & $14.5 \%$ & $-0.25[-0.83,0.32]$ & 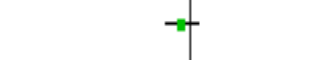 \\
\hline Macedo et al, 2012 & 7.4 & 6.7 & 86 & 8 & 6.9 & 86 & $15.0 \%$ & $-0.09[-0.39,0.21]$ & \\
\hline Monticone et al 2014 & 10 & 5 & 10 & 18 & 3 & 10 & $13.1 \%$ & $-1.86[-2.95,-0.77]$ & $\because$ \\
\hline Monticone et al, 2013 & 1.4 & 1.19 & 45 & 11.07 & 2.22 & 45 & $13.7 \%$ & $-5.38[-6.29,-4.48]$ & - \\
\hline Monticone et al, 2016 & 15.5 & 4.8 & 75 & 25.3 & 5.5 & 75 & $14.9 \%$ & $-1.89[-2.28,-1.50]$ & 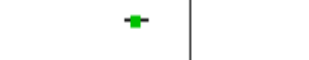 \\
\hline Total (95\% Cl) & & & 290 & & & 289 & $100.0 \%$ & $-1.62[-2.70,-0.54]$ & \\
\hline $\begin{array}{l}\text { Heterogeneity: } \text { Tau }^{2}=2 \\
\text { Test for overall effect: } Z\end{array}$ & $\begin{array}{l}.01 ; \mathrm{Chi}^{2} \\
=2.94(\end{array}$ & $\begin{array}{l}P=170.8 \\
P=0.00\end{array}$ & $\begin{array}{l}35, d f= \\
3)\end{array}$ & $6(P<0$ & $.00001)$ & $;_{1}^{2}=96$ & & & $\begin{array}{lllll}-4 & -2 & 0 & 2 & 4 \\
\text { CBT \& ETP ETP }\end{array}$ \\
\hline
\end{tabular}

Figure 5. Forest plot of the effectiveness of CBT and ITP biopsychosocial interventions on the disability index

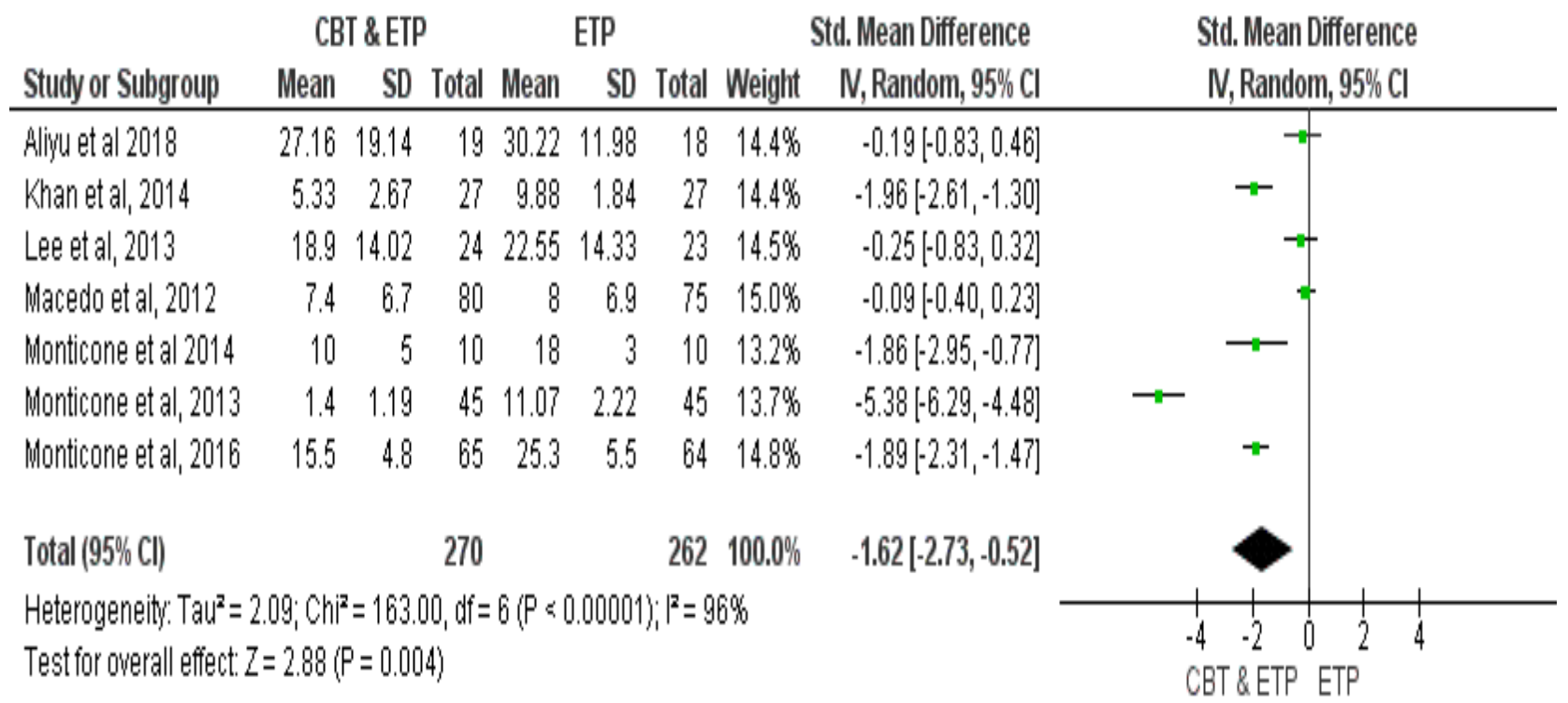

\section{Figure 6. Forest plot of the efficacy of biopsychosocial interventions for CBT and ETP on the disability index}

Figure 6 showed the forest plot of the efficacy of biopsychosocial interventions for CBT and ETP on the disability index of 532 CLBP patients. Forest plot showed the efficacy of biopsychosocial intervention therapy for CBT and ETP (intervention group) on the disability index of CLBP patients compared to ETP alone (control group) was very large with an effect size ( $d=$ $-1.62 ; 95 \% \mathrm{CI}=-2.73$ to -0.52$)$, and it was statistically significant $(\mathrm{p}<0.001)$. Heterogeneity $\left(\mathrm{I}^{2}\right)=96 \%$ indicated heterogeneous data distribution (random effect model). 


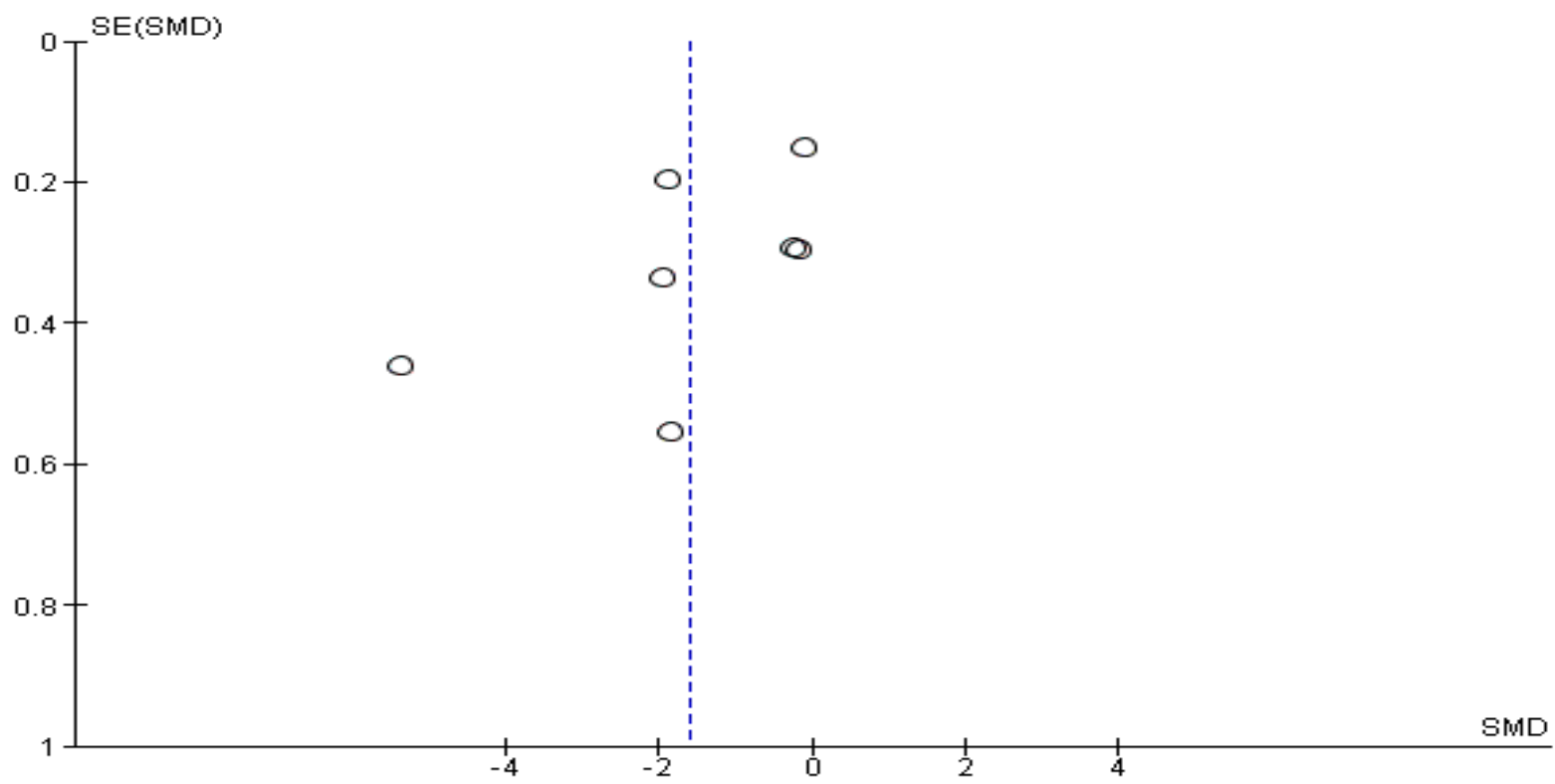

Figure 7. Funnel plot of the effectiveness of CBT biopsychosocial interventions and ETP on the disability index

Figure 7. showed that there was publication bias with an asymmetric axis indication, which was shown by the distribution of 4 funnel plots on the left and 3 funnel plots on the right. The standard error of the funnel plot on the left was 0.55 - 0.19 and the standard error for the funnel plot on the right was $0.30-0.18$.
Meanwhile, Figure 8. showed that there was publication bias with an indication of a symmetrical axis which was shown the distribution of 4 funnel plots on the left and 3 funnel plots on the right. The standard error of the funnel plot on the left was 0.55 - 0.20 and the standard error for the funnel plot on the right was $0.36-0.18$.

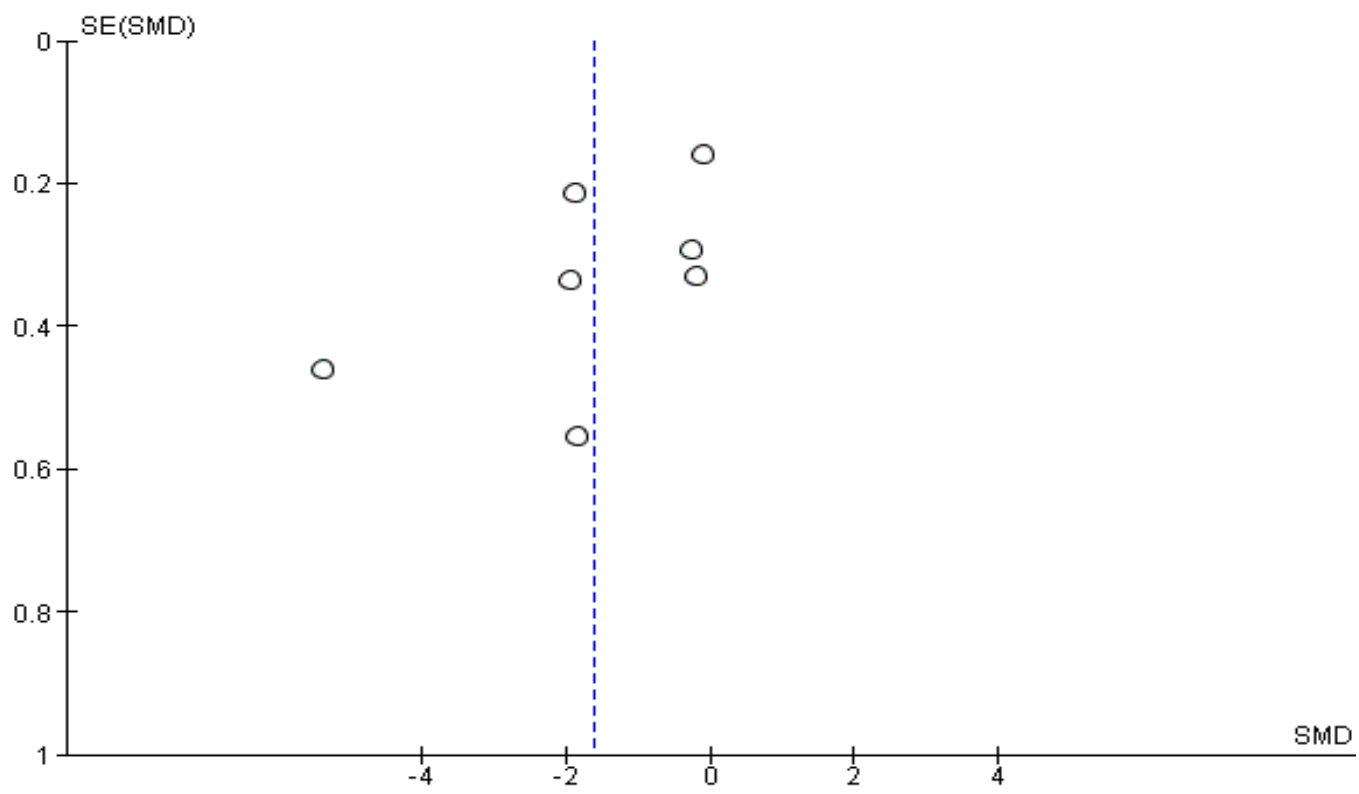

Figure 8. Funnel plot of the effectiveness of biopsychosocial interventions for CBT and ETP on the disability index 


\section{DISCUSSION}

This was a systematic review and metaanalysis of previous Randomized Control Trial studies on the effectiveness of biopsychosocial interventions for Cognitive Behavioral Therapy (CBT) and Exercise Therapy Program (ETP) on Chronic Low Back Pain (CLBP). The dependent variable in this study was Chronic Low Back Pain as a common cause of repeated referrals (Conway et al., 2019). CLBP is caused by anatomic susceptibility and non-anatomical multidimensional causative factors in the spine that fail to intervene with biomedical methods (Synnott et al., 2016). The failure of biomedical interventions in chronic pain is due to not considering the patient's cognitive and psychological factors (Velly and Mohit, 2018).

Biopsychosocial interventions for CLBP patients can improve the prognosis and quality of life of patients without pain that causes movement disabilities (Hasenbring et al., 2012). Cognitive behavioral therapy (CBT) and Exercise Therapy Program (ETP) were independent variables in this study. CBT is a biopsychosocial cognitive intervention with distraction and counseling on patterns of daily activities to control pain due to maladaptive CLBP patients (Seminowicz et al., 2013). Exercise therapy program is an exercise therapy program to establish cognitive behavioral memory of normal motor control without pain. Gradual exposure introduces the exposure phase of exercise therapy targeting the center of the fear-regulating brain memory circuit in the brain amydala (Nijs et al., 2014).

\section{1) Pain}

Pain is a protective response to the nervous system's early warning of potential tissue damage (Khalid and Tubbs, 2017). The perception of chronic pain leads to a central sensinitation mechanism resulting in nociceptive hyperexcitability that causes hyperalgesia, allodynia and expansion of the receptive field of pain (Neblett et al., 2017).

Figure 1. showed the effectiveness of biopsychosocial interventions for CBT and ETP compared to ETP intervention alone in reducing the intensity of CLBP pain was very large with an effect size $(d=-1.31 ; 95 \%$ $\mathrm{CI}=-2.39$ to $-0.23 ; \mathrm{p}<0.001)$. Meanwhile, Figure 2. showed the efficacy of biopsychosocial interventions for CBT and ETP compared to ETP intervention alone in reducing the intensity of CLBP pain which was very large with an effect size $(d=-1.31$; $95 \% \mathrm{CI}=-2.41$ to $-0.22 ; \mathrm{p}<0.001$ ).

This study concluded that there is no significant difference in Cohen's pain reduction effect between the effectiveness of CBT and ETP biopsychosocial interventions on reducing pain intensity in 579 CLBP patients compared with the efficacy of biopsychosocial interventions for CBT and ETP in 532 CLBP patients. Attrition bias did not occur because the measurement data for patients who did not complete the program were 47 patients $(8.11 \%)$ of 579 patients. These results are in accordance with the inclusion criteria, the limit of patients who did not complete the intervention process was $>25 \%$.

The absence of a significant difference effect between exercise effectiveness and efficacy is clinical evidence of patient confidence in making behavior changes to control barriers to emotional perception of pain and barriers to changes in the activity environment (Prestwich et al., 2018). The low self-efficacy of CLBP patients is due to the patient's psychological inability to carry out normal activities without pain (Bandura in Rustika, 2016). The development of pain intervention technology currently leads to a therapeutic approach based on the mechanism of the process of pain occurrence and 
not on an empiric pain therapy approach according to patient complaints (Pinzon, 2015).

Dysfunction of the corticospinal tract descending pain modulation system is the cause of the low self-efficacy of CLBP patients (Serrano et al., 2020). This mechanism is influenced by genetic potential, physical traumatic injury, emotional distress, and history of opioid abuse (Neblett et al., 2017). Patients' emotional psychological factors are directly related to controlling the intensity of catastrophizing pain and disabilities (Villanueva et al., 2020).

\section{2) Disability}

The speed of adaptation to cognitive behavior change is supported by the patient's independence in the prevention of chronic pain (Nicholas et al., 2013). This strategy is beneficial in pain control and improvement of the patient's quality of life (Chao and Ford, 2019).

The effectiveness of CBT and ETP biopsychosocial interventions compared to ETP intervention alone on the disability index of 579 CLBP patients was very large with the effect size $(d=-1.62 ; 95 \% \mathrm{CI}=-2.70$ to $-0.54 ; \mathrm{p}<0.001)$. While the efficacy of biopsychosocial interventions for CBT and ETP compared to ETP intervention alone on the disability index of 532 CLBP patients was very large with an effect size $(\mathrm{d}=-\mathbf{1 . 6 2}$; 95\% $\mathrm{CI}=-2.73$ to $-0.52 ; \mathrm{p}<0.001$ ).

In this study, there was no significant difference in Cohen's d pain reduction effect between the effectiveness of biopsychosocial interventions for CBT and ETP on the disability index of 579 CLBP patients compared with the efficacy of biopsychosocial interventions for CBT and ETP on the disability index of 532 CLBP patients. The picture of selection bias on the funnel plot of pain intensity and disability index was due to the inadequate number of studies in the meta-analysis due to the fact that not all relevant studies were published, researchers' barriers to access to paid articles and article inclusion criteria in one international language (Sedgwick, 2013). Selection bias could be due to the inadequate number of samples and the number of studies included in the metaanalysis (Lin and Chu, 2018). Errors in selecting subjects and measuring research variables by researchers can lead to metaanalysis systematic selection bias (Murti, 2018).

Systematic reviews and meta-analyzes require adequate sample size in the complex disease cases of elderly patients which are related to the statistical power of study conclusions (Hong and Park, 2012). CLBP patients do not have an adequate level of knowledge on the mechanisms of neurophysiological pain (Fereira et al., 2019). Knowledge of the clinical condition of pain is an advantage in pain treatment (Louw et al., 2016). Low level of knowledge of chronic pain causes psychological and psychiatric disorders (Fereira et al., 2019). The main component of psychological factors in pain results in parallel growth in understanding of kinesiophobia and pain that causes disabilities in activities (Louw et al., 2016).

Promotional and preventive efforts for CLBP at the clinical expression stage with cognitive behavioral therapy and functional motion aim to intervene in the biopsychosocial determinants of pain complaints so that disability limitation and rehabilitation of body functions can be achieved (Murti, 2018). Biopsychosocial intervention for CLBP patients is carried out by educating verbal persuasion by providing examples of problem-solving methods for people who want to change their effectiveness in moving without complaint (Rustika, 2016). 
The application of CBT increases selfefficacy confidence in activities without fear of movement pain (Nicholas et al., 2013). Meanwhile, the ETP intervention targets the fear-regulating memory circuit center in the brain's amydala to recognize the phases of exercise exposure with the aim of increasing self-confidence in achieving exercise success (Nijs et al., 2014). The professional multidisciplinary approach including the CBT and ETP approaches is useful in improving the neurological mechanosensitivity and psychological factors of the patient (Villanueva et al., 2020). Efficacy reflects the confidence and competence of CLBP patients in carrying out exercise program tasks to control barriers to emotional perception of pain and disabilities in social environmental activities (Prestwich et al., 2018).

\section{AUTHOR CONTRIBUTION}

Arif Fadli as the main author is the one who compiles the research concept, looks for and identifies research data. Agus Kristyanto plays a role in determining the feasibility and analyzing the article data that is inputted by the meta-analysis. Hanung Prasetya formulated the research paper report.

\section{CONFLICT OF INTEREST}

There is no conflict of interest in this study.

FUNDING AND SPONSORSHIP

This study is self-funded.

\section{ACKNOWLEDGEMENT}

Our thanks go to the electronic databasse manager of Pubmed, Googlescholar, Willey Online Library, Research Gate.

\section{REFERENCE}

Alaiti RK, Zuccolo PF, Hunziker MHL, Caneiro JP, Vlaeyen JWS, da Costa
MF (2020). Pain can be conditioned to voluntary movements through associative learning: an experimental study in healthy participants. Pain, 161(10): 2321-2329 https://doi.org/10.1097/j.pain.ooooooooooo01919.

Bagheri R, Hedayati R, Ehsani F, Boruojeni NH, Abri A, Delkhosh CT (2020). Cognitive behavioral therapy with stabilization exercises affects transverse abdominis muscle thickness in patients with chronic low back pain: A double-blinded randomized trial study. J Manipulative Physiol Therapeutics,. 43(5): 418-428. doi: 10.1016/j.jmpt.2019.03.015.

Chao YS, Ford C (2019). Cognitive behavioural therapy for chronic noncancer pain: A review of clinical effectiveness. anadian Agency for Drugs and Technologies in Health.

Cheng JOS, Cheng ST (2019). Effectiveness of physical and cognitive- behavioural intervention programmes for chronic musculoskeletal pain in adults: A systematic review and meta-analysis of randomised controlled trials. PLOS ONE. 14(10): 1-30. doi: 10.1371/journal.pone.0223367.

Conway D, Ladlow P, etc. (2019). Cognitive functional therapy (CFT)-based rehabilitation improves clinical outcomes in UK military personnel with persistent low back pain. BMJ Mil Health. 166(5): 336-341. https://doi.org/10.1136/jramc-2018-001136.

Dinakar P, Stillman AM (2016). Pathogenesis of Pain. Seminars in Pediatric Neurology. 23(3): 201-208. doi: 10.1016/j.spen.2016.10.003.

Ferreira PS, Corrêa LA, Bittencourt JV, Reis FJJ, Meziat-Filho N, Nogueira LAC (2019). Patients with chronic musculoskeletal pain present low level of the knowledge about the neurophysiology 
of pain. Europ J Physiotherapy. 1-6. https://doi.org/10.1080/21679169.2019.1676307.

Hasenbring MI, Rusu AC, et al. (2012). Epidemiology of back pain, from the laboratory to the bus stop: Psychosocial risk factors, biological mechanisms, and interventions in population-based research. in from acute to chronic back pain: Risk factors, mechanisms, and clinical implications. New York: Oxford University Press. http://dx.doi.org/10.1093/med/9780 199558902.003.0010.

Hong EP, Park JW (2012). Sample size and statistical power calculation in genetic association studies. Genomics \& Informatics. 10(2): 117. https://doi.org/10.5808/gi.2012.10.2.117.

Khalid S, Tubbs RS (2017). Neuroanatomy and Neuropsychology of Pain. Cureus, 9(10): 1-14. doi: 10.7759/cureus.1754.

Khan M, Akhter S, Soomro RR, Ali SS (2014). The effectiveness of Cognitive Behavioral Therapy (CBT) with general exercises versus general exercises alone in the management of chronic low back pain. Pakistan J Pharmaceutical Sci, 27(4): 1113-1116. https://pubmed.ncbi.nlm.nih.gov/25016276/.

Lane E, Fritz JM, Greene T, Maddox D (2018). The effectiveness of training physical therapists in pain neuroscience education on patient reported outcomes for patients with chronic spinal pain: A study protocol for a cluster randomized controlled trial. BMC Musculoskeletal Dis, 19(1): 1-8. https://doi.org/10.1186/s12891-0182269-2.

Lee WYA, Lee WCE, Law WS, WKA Lau, Leung SM, Sieh KM, Luk FYS, Law KYR (2013). Managing psychosocial contributors in low back pain patients-a randomised controlled trial.
Journal of Orthopaedics, Trauma and Rehabilitation, 17(1): 46-51. https://doi.org/10.1016/j.jotr.2012.12.002.

Lin L, Chu H (2018). Quantifying publication bias in meta-analysis. Biometrics. 74(3): 785-794. doi: 10.1111/biom.12817.

Louw A, Puentedura EJ, Zimney K, Schmidt S (2016). Know pain, know gain? A perspective on pain neuroscience education in physical therapy. J Orthop Sports Phys Ther. 46(3): 131-134. https://doi.org/10.2519/jospt.2016.0602.

Macedo LG, Latimer J, Maher CG, Hodges PW, McAuley JH, Nicholas MK, Tonkin L, et al. (2012). Effect of motor control exercises versus graded activity in patients with chronic nonspecific low back pain: A randomized controlled trial. Phys Ther. 92(3): 363-377. https://doi.org/10.2522/ptj.20110290.

Malfliet A, Kregel J, Meeus M, Danneels L, Cagnie B, Roussel N, Nijs J (2018). Patients with chronic spinal pain benefit from pain neuroscience education regardless the self-reported signs of central sensitization: secondary analysis of a randomized controlled multicenter trial. PM R. 10(12): 13301343.e1. https://doi.org/10.1016/j.pmrj.2018.04.010.

Manchikanti L, Singh V, Falco FJE, Benyamin RM, Hirsch JA (2014). Epidemiology of low back pain in Adults. Neuromodulation: Technology at the Neural Interface, 17(2): 3-10. https://doi.org/10.1111/ner.12018.

Martín MAG, Cuadrado FM, Girbes EL, Coca-López MC, Mayo-Iscar A, Cuesta-Vargas A (2019). Pain neuroscience education and physical exercise for patients with chronic spinal pain in primary healthcare: A rando- 
mized trial protocol. BMC Musculoskelet Dis. 20(1): 1-11. https://doi.org/10.1186/s12891-019-2889-1.

Monticone M, Ambrosini E, Rocca B, Cazzaniga D, Liquori V, Foti C (2016). Group-based task-oriented exercises aimed at managing kinesiophobia improved disability in chronic low back pain. Eur J Pain, 20(4): 541-551. https://doi.org/10.1002/ejp.756.

Monticone M, Ambrosini E, Rocca B, Magni S, Brivio F, Ferrante S (2014). A multidisciplinary rehabilitation program improves disability, kinesiophobia and walking ability in subjects with chronic low back pain: results of a randomized controlled pilot study. Eur Spine J. 23(10): 2105-2113. https://doi.org/10.1007/soo586-0143478-5.

Monticone M, Ferrante S, Rocca B, Baiardi P, Farra FD, Foti C (2013). Effect of a long-lasting multidisciplinary program on disability and fear-avoidance behaviors in patients with chronic low back pain: Results of a randomized controlled trial. Clin J Pain. 29(11): 929-938. https://doi.org/10.1097/ajp.obo13e31827fef7e.

Murti B (2018). Prinsip dan metodologi riset epidemiologi. Edisi ke 5. Surakarta: Program Studi Ilmu Kesehatan Masyarakat, Program Pascasarjana, Universitas Sebelas Maret.

Neblett R, Hartzell MM, Williams M, Bevers KR, Mayer TG, Gatchel RJ (2017). Use of the Central Sensitization Inventory (CSI) as a treatment outcome measure for patients with chronic spinal pain disorder in a functional restoration program. Spine J. 17(12): 1819-1829. https://doi.org/10.1016/j.spinee.2017.06.008.

Nicholas MK, Asghari A, Blyth FM, Wood BM, Murray R, McCabe R, Brnabic A, et al. (2013). Self-management intervention for chronic pain in older adults: a randomized controlled trial. Pain. 154(6): 824-35. https://doi.org/10.1016/j.pain.2013.02.009.

Nijs J, Girbés EL, Lundberg M, Malfliet A, Sterling M (2014). Exercise therapy for chronic musculoskeletal pain: Innovation by altering pain memories. Manual Therapy. 20(1): 216-20. https://doi.org/10.1016/j.math.2014. 07.004.

O’Sullivan PB, Caneiro JP, O'Keeffe M, Smith A, Dankaerts W, Fersum K, O'Sullivan K (2018). Cognitive functional therapy: An integrated behavioral approach for the targeted management of disabling low back pain. Phys Ther. 98(5): 408-423. https://doi.org/10.1093/ptj/pzyo22.

Pak DJ, Yong RJ, Kaye AD, Urman RD (2018). Chronification of pain: Mechanisms, current understanding, and clinical implications. Curr Pain Headache Rep. 22(2): 9. https://doi.org/10.1007/s11916-018-0666-8.

Pinzon R (2015). Assesmen Nyeri. Edisi 1. Yogyakarta: Betha Grafika Yogyakarta.

Prestwich A, Kenworthy J, Conner M (2018). Health behavior change: theories, methods and interventions. First Publ. New York: Routledge Taylor \& Francis Group. Available at: http://library1.org/_ads/5E4AE9DFE738DD 93B92A2B2AABCB6A7E.

Rustika IM (2016). Efikasi Diri: Tinjauan Teori Albert Bandura. Buletin Psikologi Fakultas Psikologi Universitas Gajah Mada, 20(1-2): 18-25. doi: 10.22146/bpsi.11945.

Schiavo R (2007) Health Communication: From Theory to Practice. First Edit, San Francisco: Jossey-Bass A Wiley Imprint. Available at: http://www.nc- 
bi.nlm.nih.gov/pmc/articles/PMC221 $2339 /$.

Sedgwick P (2013). Meta-analyses: how to read a funnel plot. BMJ, 1342 (March): 1-2. doi: 10.1136/bmj.f1342.

Seminowicz DA, Shpaner M, Keaser ML, Krauthamer GM, Mantegna J, Dumas JA, Newhouse PA, et al. (2013). Cognitive-behavioral therapy increases prefrontal cortex gray matter in patients with chronic pain. J Pain. 14(12): 1573-1584. https://doi.org/10.1016/j.jpain.2013.07.020.

Serrano GB, Rodrigues LP, Schein B, Zortea M, Torres ILS, Fregni F, Caumo W (2020). The hypnotic analgesia suggestion mitigated the effect of the transcranial direct current stimulation on the descending pain modulatory system: A proof of concept study. J Pain Res. 13: 2297-2311. https://doi.org/10.2147/jpr.s253747.

Synnott A, O'Keeffe M, Bunzli S, Dankaerts W, O'Sullivan P, Robinson K, O'Sullivan K (2016). Physiotherapists report improved understanding of and attitude toward the cognitive, psychological and social dimensions of chronic low back pain after cognitive functional therapy training: a qualitative study. J Physiother. 62(4): 215-221. https://doi.org/10.1016/j.jphys.2016.08.002.

Ung H, Brown JE, Johnson KA, Younger J, Hush J, Mackey S (2014). Multivariate classification of structural MRI data detects chronic low back pain. Cerebral Cortex, 24(4): 1037-1044. doi: 10.1093/cercor/bhs378.

Velly AM, Mohit S (2018). Epidemiology of pain and relation to psychiatric disorders. Progress in Neuro-Psychopharmacology and Biological Psychiatry, 87: 159-167. doi: 10.1016/j.pnpbp.2017.05.012.

Villanueva ILDU, Alacreu HB, Carnero JF, Touche RL (2020). Pain management using a multimodal physiotherapy program including a biobehavioral approach for chronic nonspecific neck pain: a randomized controlled trial', Physiotherapy Theory and Practice, 36(1): 45-62. doi: 10.1080/09593985.2018 .1480678 . 